\title{
Formation and Regeneration of Shape-Selective ZSM-35 Catalysts for $n$-Butene Skeletal Isomerization to Isobutene
}

\author{
Quan Xu \\ China University of Petroleum Bejing, xuquan@cup.edu.cn \\ Wenjing Yang \\ China University of Petroleum Bejing \\ Zhiwei Chen \\ China University of Petroleum Bejing \\ Yingchun Ye \\ China University of Petroleum Bejing \\ Yan Luo \\ West Virginia University
}

See next page for additional authors

Follow this and additional works at: https://researchrepository.wvu.edu/faculty_publications

Part of the Chemical Engineering Commons

\section{Digital Commons Citation}

Xu, Quan; Yang, Wenjing; Chen, Zhiwei; Ye, Yingchun; Luo, Yan; Street, Jason; Zhou, Hongjun; and Xu, Chunming, "Formation and Regeneration of Shape-Selective ZSM-35 Catalysts for n-Butene Skeletal Isomerization to Isobutene" (2018). Faculty \& Staff Scholarship. 1539.

https://researchrepository.wvu.edu/faculty_publications/1539

This Article is brought to you for free and open access by The Research Repository @ WVU. It has been accepted for inclusion in Faculty \& Staff Scholarship by an authorized administrator of The Research Repository @ WVU. For more information, please contact beau.smith@mail.wvu.edu. 
Authors

Quan Xu, Wenjing Yang, Zhiwei Chen, Yingchun Ye, Yan Luo, Jason Street, Hongjun Zhou, and Chunming $\mathrm{Xu}$

This article is available at The Research Repository @ WVU: https://researchrepository.wvu.edu/faculty_publications/ 


\title{
Formation and Regeneration of Shape-Selective ZSM-35 Catalysts for $\boldsymbol{n}$-Butene Skeletal Isomerization to Isobutene
}

\author{
Quan $\mathrm{Xu},{ }^{*}, \dagger \odot$ Wenjing Yang, ${ }^{\dagger}$ Zhiwei Chen, ${ }^{*}{ }^{\dagger}$ Yingchun Ye, ${ }^{\dagger}$ Yan Luo, ${ }^{\ddagger}$ Jason Street, ${ }^{\S \odot}$
} Hongjun Zhou, ${ }^{\dagger}$ and Chunming $\mathrm{Xu}^{\dagger}$

\author{
${ }^{\dagger}$ State Key Laboratory of Heavy Oil Processing, Beijing Key Laboratory of Biogas Upgrading Utilization, China University of \\ Petroleum Beijing (CUPB), Beijing 102249, China \\ ${ }^{\ddagger}$ Department of Chemical Engineering, West Virginia University, Morgantown, West Virginia 26506, United States \\ ${ }^{\S}$ Department of Sustainable Bioproducts, Mississippi State University, Starkville, Mississippi State 39762, United States
}

\section{Supporting Information}

\begin{abstract}
Skeletal isomerization of $n$-butene to isobutene was performed over formed ZSM-35 zeolites in a lab-scale, fixed-bed reactor. The formation conditions to produce isobutene with zeolites were varied to determine the most advantageous binding agent (pseudo-boehmite) amount and steam dealumination conditions. The optimal binding agent amount was $20 \mathrm{wt} \%$. Steam dealumination stabilized the catalysts and enhanced the catalytic performance because of the stable $\mathrm{Si} / \mathrm{Al}$ framework and suitable acidity. The optimized process conditions involved a reaction temperature of $410{ }^{\circ} \mathrm{C}$, a weight hourly space velocity of $5 \mathrm{~h}^{-1}$, and an $n$-butene concentration in feedstock of $50 \%$. After being on-stream for 296 h, the catalysts were stable and were able to be regenerated

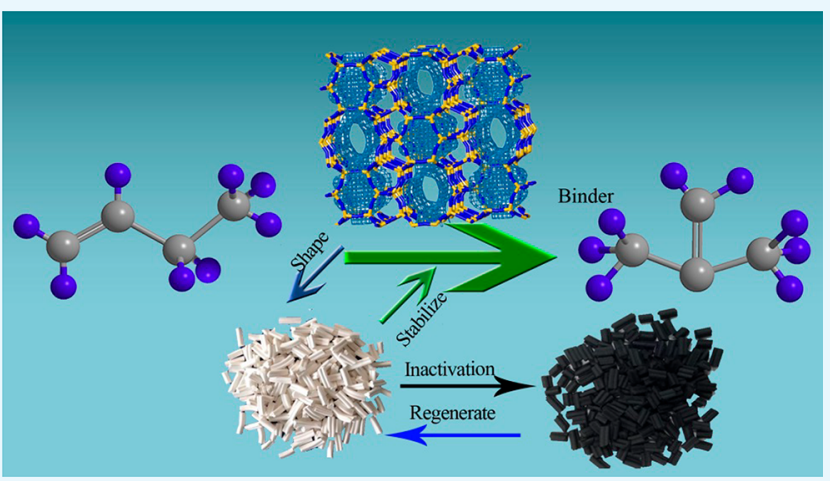
with a comparable catalytic performance. An isobutene yield of 33-43 wt \% was achieved, and the selectivity of isobutene was higher than $90 \%$ after the reaction was carried out for longer than $15 \mathrm{~h}$. Carbon deposition modified the pore structure to enhance the selectivity of isobutene because of the selective shape effect. This study shows promising results for future industrialization of the skeletal isomerization of $n$-butene to isobutene in the presence of optimized ZSM- 35 catalysts.
\end{abstract}

\section{INTRODUCTION}

Isobutene is an important organic chemical material used in the production of methyl tertiary butyl ether (MTBE), tertiary butanol, methyl methacrylate, butyl rubber, and other highly valued chemicals. ${ }^{1,2}$ Currently, the major conversion pathways for the production of isobutene include the skeletal isomerization of $n$-butene, dehydrogenation of isobutane, and isomerization dehydrogenation of $n$-butane. ${ }^{3}$ The skeletal isomerization of $n$-butene has obtained increased attention to produce MTBE and other highly valued products. This technology also enhances the utilization of $\mathrm{C} 4$ and increases the supply of isobutene. The skeletal isomerization of $n$-butene is dependent on the acid catalysis technology. Researchers have developed $\mathrm{Al}_{2} \mathrm{O}_{3}$-based catalysts and various types of zeolites used in the skeletal isomerization of $n$-butene. ${ }^{3,4} \mathrm{Al}_{2} \mathrm{O}_{3}$-based catalysts have been applied in the early stage of isomerization; however, this technology has been gradually replaced because of low catalytic activity and poor stability. Ferrierite ${ }^{5}$ has been heavily researched and utilized because of the special pore structure and size to selectively produce isobutene. In addition, ferrierite is becoming an attractive catalyst to use in the industry because of its strong carbon tolerance. ${ }^{4}$ Ferrierite catalysis occurs over a lifetime of hundreds of hours, and this type of material is included but not limited to SAPO-11, MCM-22/49, ZSM-5, ZSM-35, and ZSM-22/23. ${ }^{4-7}$ Promising catalytic activity has been achieved, especially with the tenmembered ring (MR) zeolite ZSM-35.,

Properties such as acid strength (weak and strong), Brønsted (B) or Lewis (L) acid type, and active site distribution have a serious effect on the catalytic performance of the zeolite. ${ }^{10-13}$ The acid strength required for acid-catalyzed isomerization reactions can be ranked as the following: cracking $\approx$ oligomerization $>$ skeletal isomerization $>$ double-bond shift and cis-trans isomerism. ${ }^{5,14,15}$ Moreover, the isolated acid sites reduce the number of side reactions. ${ }^{16-18}$ The acidity of zeolites can be adjusted by changing the $\mathrm{Si} / \mathrm{Al}$ ratio, replacing alumina in the framework with other elements, or modifying the preparation/forming process.

Carbon deposition is an inevitable process in the skeletal isomerization of $n$-butene to isobutene. A small amount of carbon deposition enhances the selectivity, but too much carbon deposition leads to the deactivation of the cata-

Received: February 23, 2018

Accepted: July 12, 2018

Published: July 24, 2018 

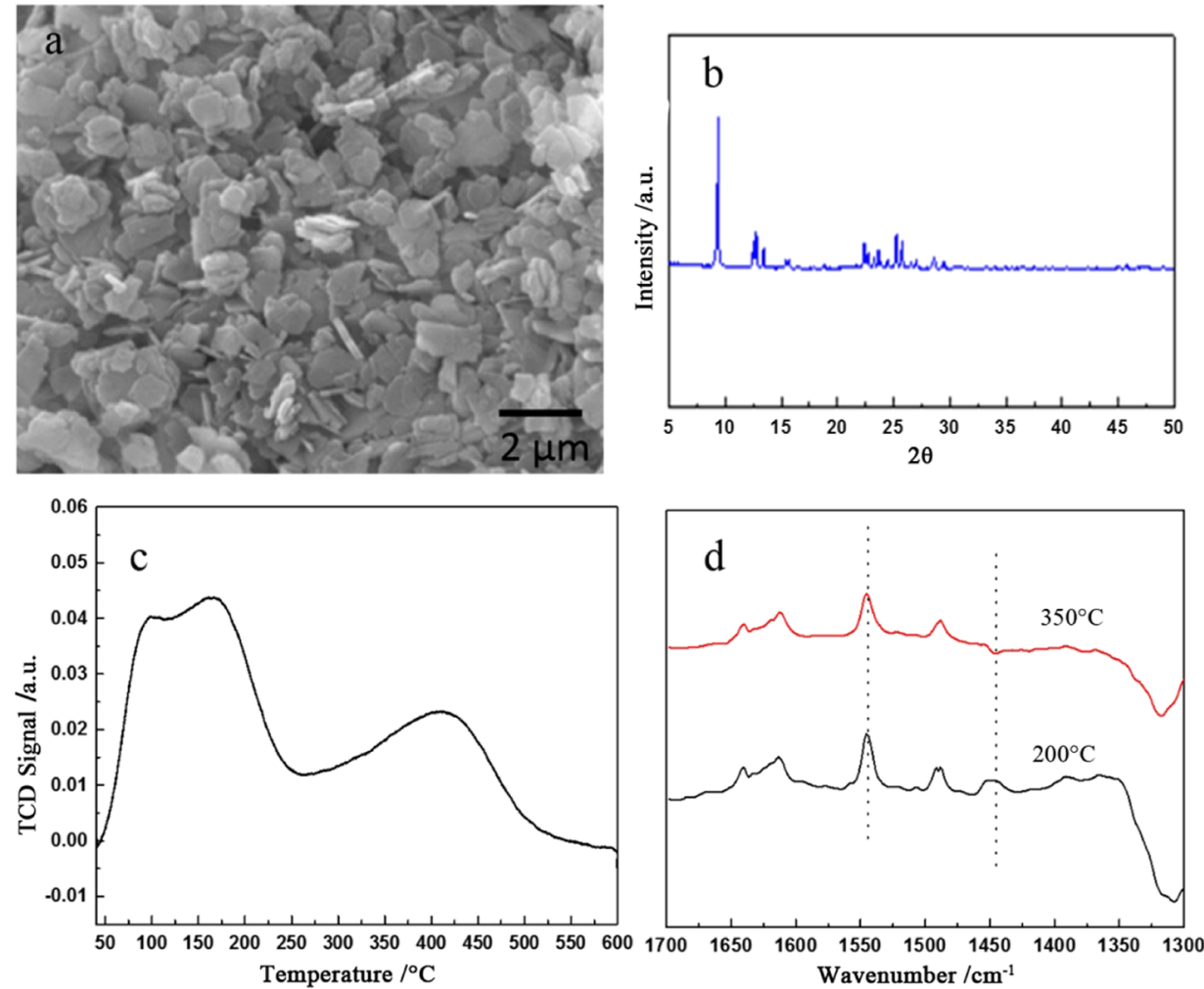

Figure 1. Synthesized ZSM-35 zeolite powder. (a) SEM image, (b) XRD pattern, (c) $\mathrm{NH}_{3}$-TPD profile, and (d) Py-IR profiles at the desorption temperatures of 200 and $350{ }^{\circ} \mathrm{C}$.

lysts. ${ }^{19-22}$ Wattanakit et al. ${ }^{23}$ studied the effects of various reaction times on carbon deposition. The carbon mainly blocked the 8-MR pore channel, but only a small amount of carbon was deposited on the 10-MR pore channel in the initial stage of the reaction. As the reaction continued, the 8-MR pore channel was blocked completely, whereas the 10-MR pore channel only had a slight amount of carbon deposition. Therefore, the catalyst could retain a high catalytic performance over a long period of time. The proper reactor type and reaction conditions reduce coke deposition on the catalyst. Modification of the catalyst components or structure also has the potential to reduce coking. Regeneration of catalysts can enhance the comprehensive economic benefits of industrial catalytic devices, reduce the consumption of catalysts, and protect the environment. The regeneration approach relates to deactivation reasons. Carbon deposition involves the physical coverage of the catalyst without any destruction of the structure of the catalysts. Therefore, combustion of the carbon on the catalyst or steam regeneration can be used to remove carbon deposition. $^{21,24}$

Although ZSM-35 has been applied as an isomerization catalyst, there is not a well-defined relationship between the catalytic performance and the active sites on the zeolite. There is also not a well-defined relationship between carbon deposition and catalyst stability because of limited characterization technologies. The objective of this study was to optimize the forming process to prepare superior catalysts in terms of the pseudo-boehmite binder amount and steam dealumination. This study also seeks to determine the reaction process conditions most conducive to maximize isobutene yield in terms of the reaction temperature, feedstock concentration, and weight hourly space velocity (WHSV).
Furthermore, coke deposition and catalyst regeneration were also investigated.

\section{RESULTS AND DISCUSSION}

Characterization of the Synthesized ZSM-35 Zeolite Powder. Scanning electron microscopy (SEM) images (Figure 1a) clearly showed that the synthesized ZSM-35 zeolite powder were present as rectangular shapes and had a sheetlike morphology. The particle size was relatively uniform. The X-ray diffraction (XRD) pattern of the synthesized ZSM35 zeolite (Figure $1 \mathrm{~b}$ ) only had characteristic diffraction peaks at $2 \theta=9.4^{\circ}, 22.4^{\circ}, 22.7^{\circ}, 23.3^{\circ}, 23.7^{\circ}, 24.5^{\circ}$, and $25.3^{\circ}$, indicating that the synthesized ZSM-35 zeolites were wellcrystallized and pure. ${ }^{7}$ The surface area and pore volume measured by $\mathrm{N}_{2}$ adsorption-desorption (Table 1) revealed

Table 1. $\mathrm{N}_{2}$ Adsorption-Desorption Analysis of the Synthesized ZSM-35 Zeolite Powder

\begin{tabular}{ccccc} 
catalysts & $\begin{array}{c}\text { BET surface } \\
\text { area, } \mathrm{m}^{2} / \mathrm{g}\end{array}$ & $\begin{array}{c}\mathrm{BJH} V_{\mathrm{p}}, \\
\mathrm{mL} / \mathrm{g}\end{array}$ & $\begin{array}{c}\mathrm{t} \text {-microspore } V_{\mathrm{p}}, \\
\mathrm{mL} / \mathrm{g}\end{array}$ & $\mathrm{D} \mathrm{nm}$ \\
$\begin{array}{c}\text { synthesized } \\
\text { ZSM-35 }\end{array}$ & 327.5 & 0.157 & 0.140 & 0.54 \\
\hline
\end{tabular}

that the synthesized ZSM-35 zeolite possessed a large surface area of $327.5 \mathrm{~m}^{2} / \mathrm{g}$, and the pore volume was $0.157 \mathrm{~mL} / \mathrm{g}$. These results can be attributed to the small zeolite grains that were well-crystallized. The acid strength and type of the synthesized ZSM-35 zeolite were analyzed by temperatureprogrammed desorption of ammonia ( $\left.\mathrm{NH}_{3}-\mathrm{TPD}\right)$ and Pyinfrared (IR), respectively. $\mathrm{NH}_{3}$-TPD profiles (Figure 1c) indicated that the synthesized ZSM-35 had two acid types, namely weak acid and strong acid, located at 100-200 and 
$300-500{ }^{\circ} \mathrm{C}$, respectively. Py-IR spectra of pyridine adsorption at 200 and $350{ }^{\circ} \mathrm{C}$ (Figure 1d) inferred that the synthesized zeolite had a large amount of Brønsted acidic sites (B) and a small amount of Lewis acidic sites (L) located at 1540 and $1450 \mathrm{~cm}^{-1}$, respectively (Table 2 ).

Table 2. Brønsted (B) and Lewis (L) Acidic Site Distribution of the Synthesized ZSM-35 Zeolite Powder Analyzed by Py-IR

\begin{tabular}{|c|c|c|c|c|c|c|}
\hline \multirow[b]{2}{*}{ catalyst } & \multicolumn{2}{|c|}{$200{ }^{\circ} \mathrm{C}, \mu \mathrm{mol} / \mathrm{g}$} & \multicolumn{2}{|c|}{$350{ }^{\circ} \mathrm{C}, \mu \mathrm{mol} / \mathrm{g}$} & \multirow{2}{*}{$\frac{200{ }^{\circ} \mathrm{C}}{\mathrm{L} / \mathrm{B}}$} & \multirow{2}{*}{$\frac{350^{\circ} \mathrm{C}}{\mathrm{L} / \mathrm{B}}$} \\
\hline & $\mathrm{L}$ & B & $\mathrm{L}$ & B & & \\
\hline $\begin{array}{l}\text { synthesized } \\
\text { ZSM-35 }\end{array}$ & 0.432 & 1.284 & 0.048 & 1.134 & 0.337 & 0.042 \\
\hline
\end{tabular}

Optimization of the Forming Process for ZSM-35 Catalysts. The forming of the catalysts is important for catalytic performance and for the stability of the catalysts in the industry. In this study, the amount of the pseudo-boehmite binder and the steam dealumination were selected to be studied. All catalytic reactions in the formation were performed under reaction conditions, $T=410{ }^{\circ} \mathrm{C}, P=0.1 \mathrm{MPa}$, WGSH $=$ $5 \mathrm{~h}^{-1}$, and $n$-butene concentration $=50 \%$. Details of the feedstock components are listed in Table S1.

Effects of the Pseudo-Boehmite Binder Amount on the Formed ZSM-35 Catalysts. The binder was applied to increase the bond strength between material particles to improve adhesion. In this study, pseudo-boehmite was chosen as the binder to investigate the shaped catalysts' strength and catalytic performance. The results (Table 3 ) showed that the

Table 3. Effects of Binder Amounts on the Crushing Strength of the Formed Catalyst

\begin{tabular}{lcccc}
\multicolumn{1}{c}{ item } & Cat.-0 & Cat.-10 & Cat.-20 & Cat.-40 \\
binder amount, wt \% & 0 & 10 & 20 & 40 \\
crushing strength, $\mathrm{N} \cdot \mathrm{cm}^{-1}$ & 8 & 14 & 20 & 23 \\
\hline
\end{tabular}

crushing strength of the catalyst increased as the binder amount increased from 0 to 40 wt $\% . \mathrm{NH}_{3}$-TPD profiles (Figure 2a) indicated that the catalysts had an increase in acidity as the binder amount increased from 0 to $20 \mathrm{wt} \%$. However, when the binder amount increased from 20 to $40 \mathrm{wt}$ $\%$, the desorption peak area showed a reverse effect and the weak acidic sites decreased to an amount even lower than that of the Cat.-0. The reason for the decreased acidity was attributed to surface hydroxyl condensation, which took place during the molding and calcination processes. Py-IR spectroscopy (Figure $2 \mathrm{~b}$ and Table 4 ) inferred that the total Lewis acidic sites (L) located at $1450 \mathrm{~cm}^{-1}$ increased from 0.1 to $0.45 \mu \mathrm{mol} / \mathrm{g}$ as the binder percentage increased from 0 to 40 wt \%. However, Brønsted acidic sites (B) located at $1540 \mathrm{~cm}^{-1}$ exhibited the opposite tendency and decreased as the binder amount increased, as shown in Table 4 . The L/B ratios at weak and strong acidic sites increased as the binder amount increased.

Catalytic performance results (Figure $2 \mathrm{c}, \mathrm{d}$ ) indicated that the conversion of $n$-butene and the yield of isobutene increased as the binder amount increased from 0 to $20 \mathrm{wt} \%$. However, the continuous increase of the binder amount to $40 \mathrm{wt} \%$ led to the decrease of $n$-butene conversion and isobutene yield. This result is consistent with the $\mathrm{NH}_{3}$-TPD and Py-IR results, indicating that the conversion of $n$-butene was related to the acidity of the catalyst. The selectivity of isobutene increased as the amount of binder increased from 0 to $40 \mathrm{wt} \%$. This may have occurred because $\mathrm{Al}_{2} \mathrm{O}_{3}$ deposited on the inner pores of the structured zeolites decreased the size of the channels, which favored a single molecule reaction. Therefore, the optimal binder amount was $20 \mathrm{wt} \%$ to generate isobutene.

Effect of Steam Dealumination on Formed ZSM-35 Catalysts. Hydrothermal treatment is an effective approach to enhance the stability of the catalyst and the selectivity of the desired products by adjusting the acidity and structure of the catalyst. ${ }^{26}$ In this study, the formed ZSM-35 with 20 wt \% pseudo-boehmite binder was selected for hydrothermal treatment. $\mathrm{NH}_{3}$-TPD profiles (Figure $3 \mathrm{a}$ ) indicated that the weak acidic site amount did not change, whereas the strong acidic sites decreased slightly. However, the Py-IR spectra (Figure $3 \mathrm{~b}$ and Table 5) inferred that the $\mathrm{B}$ acid type amount decreased substantially after hydrothermal treatment, whereas the $\mathrm{L}$ acid type amount increased largely. The solid-state nuclear magnetic resonance (NMR) spectra ${ }^{29} \mathrm{Si}$ of the hydrothermal and nonhydrothermal treatment are shown in Figure 3c. The shift of $-100.2419 \mathrm{ppm}$ was assigned to $\mathrm{Q}(2 \mathrm{Al})$; the shift of -105.3952 and $-108.6855 \mathrm{ppm}$ were assigned to $\mathrm{Q}(1 \mathrm{Al})$; the shift of $-112.0363,-114.7540$, and $-116.4758 \mathrm{ppm}$ were characterized as $\mathrm{Q}(0 \mathrm{Al}) .^{26,27}$ The calculated framework $\mathrm{Si} / \mathrm{Al}$ molar ratio for the nonhydrother$\mathrm{mal}$ and hydrothermal treated catalysts were 56.50 and 84.90 using the following equation, respectively, indicating that the framework $\mathrm{Al}$ atoms were partly removed. The removed framework $\mathrm{Al}$ atoms were responsible for the decreased $\mathrm{B}$ acid type amount and the increased L/B ratio, which was consistent with the reported work. ${ }^{27}$

$$
n_{\mathrm{Si}} / n_{\mathrm{Al}}=\sum_{n=0}^{4} I_{\mathrm{Si}(n \mathrm{Al})} / \sum_{n=0}^{4} 0.25 \cdot n \cdot I_{\mathrm{Si}(n \mathrm{Al})}
$$

The catalytic performance results (Figure 3d,e) indicated that the conversion of $n$-butene in the presence of hydrothermal-treated catalysts was always higher than that of the fresh catalysts during the isomerization reaction. The hydrothermal-treated catalysts showed less isobutene selectivity in the first $40 \mathrm{~h}$ but reached the same level in the later $60 \mathrm{~h}$. Moreover, the hydrothermal-treated catalyst showed only a slightly lower yield of isobutene during the first $20 \mathrm{~h}$; however, it had a higher and stable isobutene yield after $40 \mathrm{~h}$. These results implied that the hydrothermal treatment enhanced the stability of the zeolite by removing the active sites responsible for catalyzing oligomerization and cracking reactions. ${ }^{5,28}$ The decreased strong acidic sites in $\mathrm{NH}_{3}$-TPD results supported this conclusion, which led to coking and catalyst deactivation. The slight increased yield of propene was possibly due to the increased $\mathrm{L}$ acidic type, which was the active site for catalytic cracking. Another reason was possibly because the secondary pore was formed during hydrothermal treatment, which was beneficial for molecular diffusion and cracking of low polyolefin.

Optimization of Skeletal Isomerization Process Conditions. The process conditions such as the reaction temperature, $n$-butene concentration, and WHSV have significant effects on the isomerization process. ${ }^{29}$ Therefore, these three parameters have been systematically investigated in this work. Reaction temperature studies (Figure 4a,b) indicated that the conversion of $n$-butene, the selectivity of isobutene, and the yield of isobutene all increased as the 

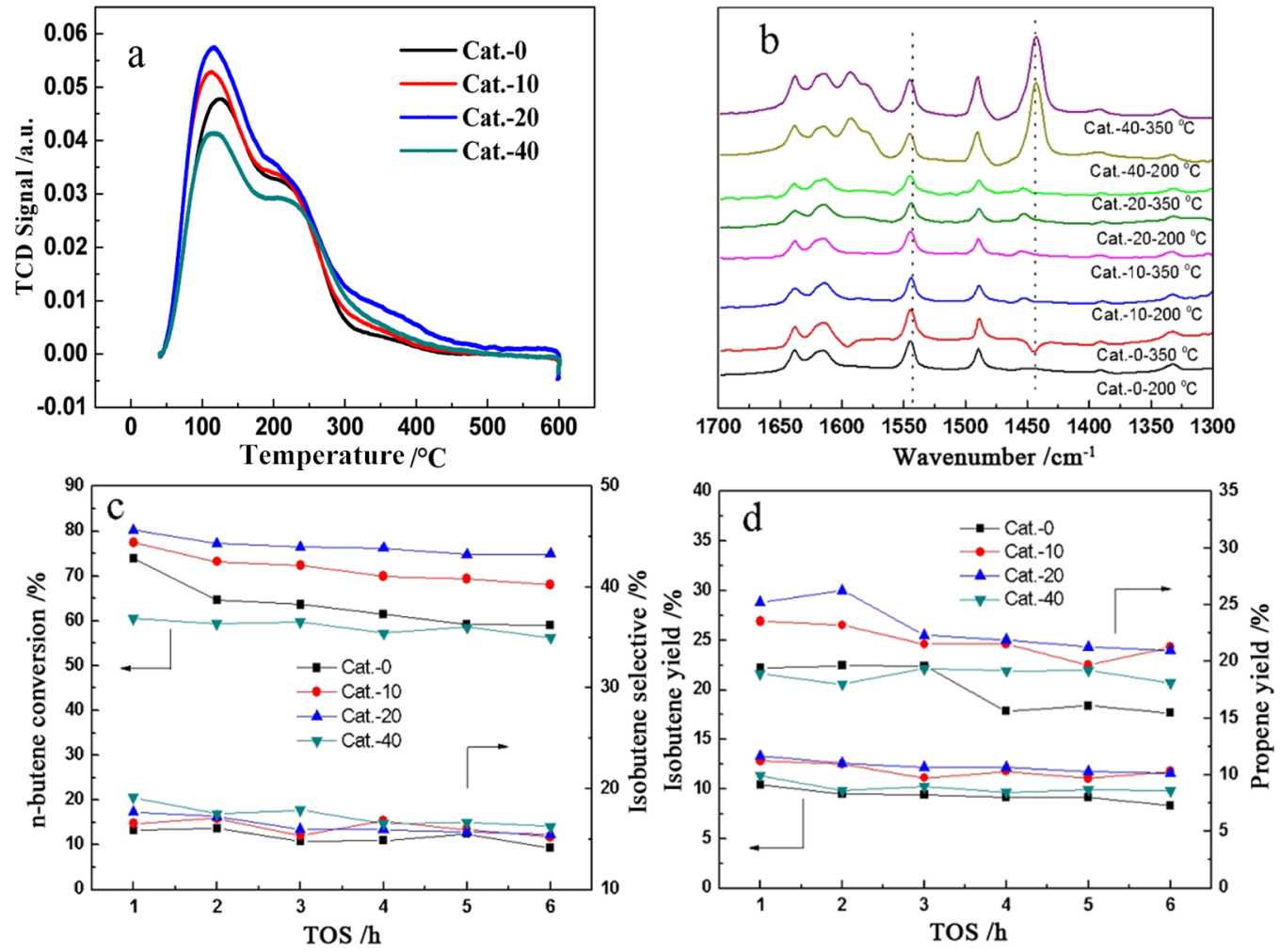

Figure 2. (a) $\mathrm{NH}_{3}$-TPD profiles of the structured catalyst with various binder amounts, (b) Py-IR profiles of the sample desorption temperatures at the temperatures of 200 and $350{ }^{\circ} \mathrm{C}$, and $(\mathrm{c}, \mathrm{d})$ effects of the binder amounts on the catalytic activities (reaction conditions: $T=410{ }^{\circ} \mathrm{C}, P=0.1$ $\mathrm{MPa}$, WGSH $=5 \mathrm{~h}^{-1}$, and $n$-butene concentration $=50 \%$; details of the feedstock components listed in Table S1).

Table 4. Brønsted (B) and Lewis (L) Acidic Site Distribution of the Formed Catalyst with Various Binder Amounts

\begin{tabular}{|c|c|c|c|c|c|c|}
\hline \multirow[b]{2}{*}{ catalysts } & \multicolumn{2}{|c|}{$200{ }^{\circ} \mathrm{C}, \mu \mathrm{mol} / \mathrm{g}$} & \multicolumn{2}{|c|}{$350{ }^{\circ} \mathrm{C}, \mu \mathrm{mol} / \mathrm{g}$} & \multirow{2}{*}{$\frac{200^{\circ} \mathrm{C}}{\mathrm{L} / \mathrm{B}}$} & \multirow{2}{*}{$\frac{350{ }^{\circ} \mathrm{C}}{\mathrm{L} / \mathrm{B}}$} \\
\hline & $\mathrm{L}$ & B & $\mathrm{L}$ & B & & \\
\hline Cat.-0 & 0.078 & 0.970 & 0.022 & 0.891 & 0.080 & 0.025 \\
\hline Cat.-10 & 0.086 & 0.817 & 0.036 & 0.759 & 0.105 & 0.047 \\
\hline Cat.-20 & 0.158 & 0.688 & 0.069 & 0.672 & 0.230 & 0.103 \\
\hline Cat.-40 & 0.311 & 0.633 & 0.144 & 0.626 & 0.491 & 0.230 \\
\hline
\end{tabular}

reaction temperature increased from 350 to $410{ }^{\circ} \mathrm{C}$. However, the conversion of $n$-butene decreased, whereas the selectivity and yield of isobutene increased slightly when the temperature was continuously increased to $450{ }^{\circ} \mathrm{C}$. The yield of heavy components $\left(\mathrm{C}_{5}^{+}\right)$increased slightly and that of propene substantially increased as the temperature increased from 350 to $450{ }^{\circ} \mathrm{C}$. The decrease of $n$-butene conversion was probably due to side reactions that occurred, involving cracking and coking of polymerized products at high reaction temperatures. The selectivity of isobutene increased because of the channel modification from carbon deposition and the interaction between kinetics and thermodynamics. ${ }^{29,30}$ Considering the catalyst stability and low byproduct production, the optimal temperature for the isomerization reaction was $410{ }^{\circ} \mathrm{C}$.

The $n$-butene concentration study (Figure $4 \mathrm{c}, \mathrm{d}$ ) inferred that the conversion of $n$-butene and the yield of isobutene decreased even though the selectivity increased slightly as the $n$-butene concentration increased. The yield of $\mathrm{C}_{5}{ }^{+}$increased, but the yield of propene decreased. The high concentration of the precursor feedstock increased the partial pressure of $n$ butene, which was beneficial for the oligomerization of olefins; however, the increased concentration decreased the contact frequency between $n$-butene and the active sites on the catalyst, which resulted in an insufficient reaction. Generally, the initial reaction stage involved the bimolecular mechanism. ${ }^{8}$ As the concentration of $n$-butene increased, the yield of $\mathrm{C}_{5}^{+}$ increased because the less contact frequency increased the amount of unreacted biopolymers. Moreover, the higher $n$ butene concentration was beneficial for dimerization to produce more carbon, which modified the pore channel by covering the strong acid sites; therefore, the selectivity of isobutene increased. The catalysts have great adaptability to the concentration range of $n$-butylene; however, an extremely high concentration of $n$-butene resulted in a high yield of byproducts and rapid carbon deposition. Therefore, low concentrations of $n$-butene were most beneficial for favoring the isomerization reactions.

Generally, when the amount of catalyst loading is fixed, the device-processing capacity increased, but the contact time of raw material and catalyst was shortened with the increase of WHSV, which led to a decreased conversion degree of the raw material and the yield of isobutylene. On the contrary, the contact time of the material and the catalyst was prolonged, but the byproduct increased and the selectivity of isobutene decreased with the decrease of WHSV. The n-butene conversion and yield of isobutene decreased with the increase of WHSV. The reason for this was because the contact efficiency between $n$-butene and the catalyst active sites decreased as the WHSV increased. In addition, the short contact time decreased the possibility of occurrence of polymerization reactions. ${ }^{31}$ Therefore, although the conversion of $n$-butylene and the yield of isobutylene are high when the WHSV is low, considering the selectivity and process capacity 

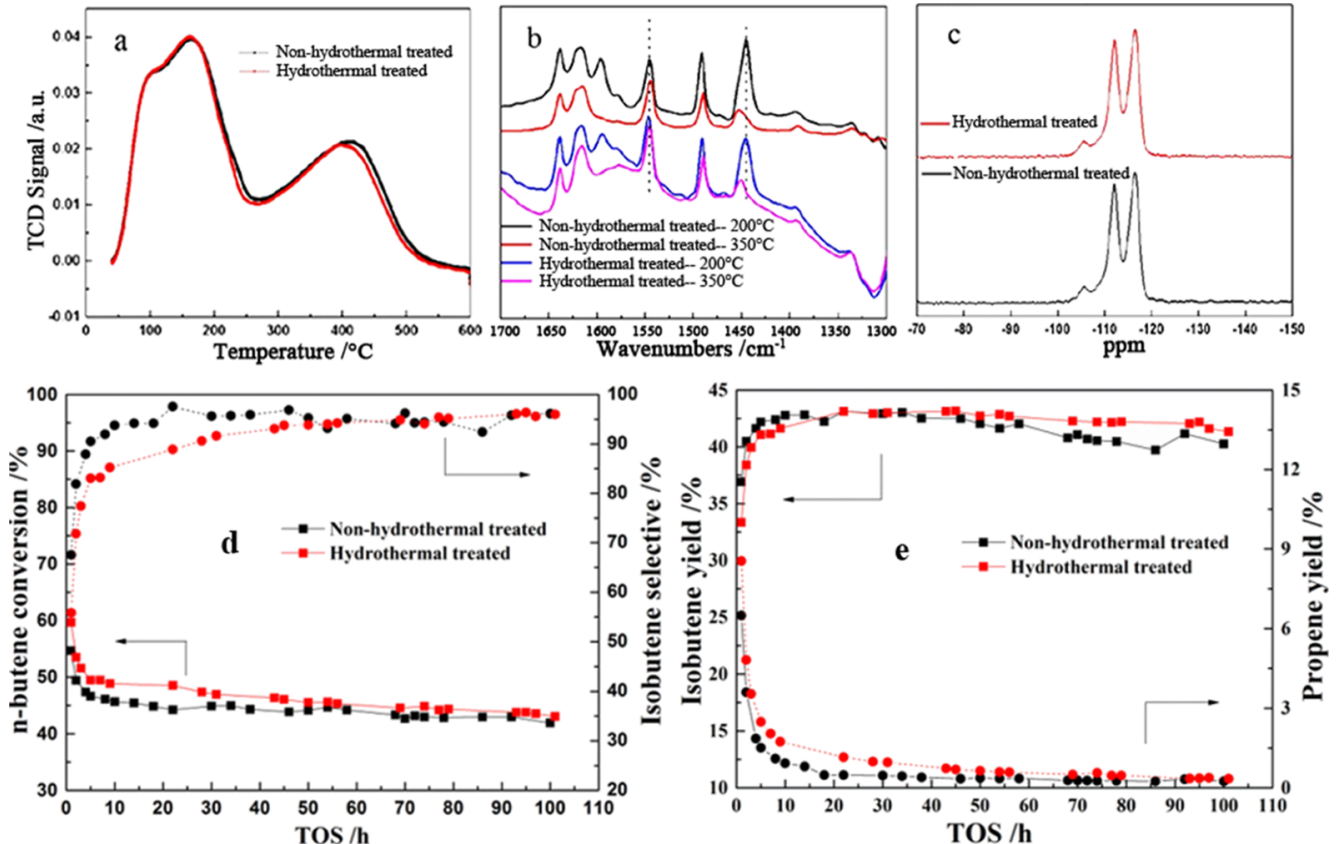

Figure 3. (a) $\mathrm{NH}_{3}$-TPD profiles, (b,c) Py-IR of the sample desorption at the temperatures of 200 and $350{ }^{\circ} \mathrm{C}$, (c) ${ }^{29} \mathrm{Si}$ MAS NMR of nonheattreated and heat-treated samples, and (d,e) effects of heat treatment on the catalytic activity (reaction conditions: $T=410{ }^{\circ} \mathrm{C}, P=0.1 \mathrm{MPa}, \mathrm{WGSH}$ $=5 \mathrm{~h}^{-1}$, and $n$-butene concentration $=50 \%$; details of the feedstock components are listed in Table S1).

Table 5. Brønsted (B) and Lewis (L) Acidic Site Distribution of the Nonhydrothermal- and Hydrothermal-Treated Zeolite

\begin{tabular}{|c|c|c|c|c|c|c|}
\hline \multirow[b]{2}{*}{ items } & \multicolumn{2}{|c|}{$200{ }^{\circ} \mathrm{C}, \mu \mathrm{mol} / \mathrm{g}$} & \multicolumn{2}{|c|}{$350{ }^{\circ} \mathrm{C}, \mu \mathrm{mol} / \mathrm{g}$} & \multirow{2}{*}{$\frac{200{ }^{\circ} \mathrm{C}}{\mathrm{L} / \mathrm{B}}$} & \multirow{2}{*}{$\frac{350^{\circ} \mathrm{C}}{\mathrm{L} / \mathrm{B}}$} \\
\hline & $\mathrm{L}$ & B & $\mathrm{L}$ & $\mathrm{B}$ & & \\
\hline hydrothermal-treated $\mathrm{ZSM}-35\left(\mathrm{SiO}_{2} / \mathrm{Al}_{2} \mathrm{O}_{3}=70\right)$ & 1.003 & 0.837 & 0.228 & 0.711 & 1.199 & 0.321 \\
\hline nonhydrothermal-treated $\mathrm{ZSM}-35\left(\mathrm{SiO}_{2} / \mathrm{Al}_{2} \mathrm{O}_{3}=70\right)$ & 0.482 & 0.897 & 0.187 & 0.871 & 0.538 & 0.215 \\
\hline
\end{tabular}

of isobutylene, the optimal WHSV condition for the skeletal isomerization of $n$-butene was $5 \mathrm{~h}^{-1}$ (Figure $4 \mathrm{e}-\mathrm{g}$ ).

Stability and Regeneration of ZSM-35 Catalysts. The stability of the catalyst is a key factor for industrialization. Carbon deposition inactivation is an inevitable process, and the carbon type determined the regeneration process used on catalysts, which already underwent the reaction. During the initial reaction time of $20 \mathrm{~h}$, the conversion of $n$-butene decreased rapidly from 60 to $45 \%$, whereas the selectivity of isobutene increased from 55 to $90 \%$ (Figure $5 a-c$ ). This initial phenomenon matched the reported bimolecular mechanism, namely, the initial polymerized byproducts were deposited inside the pore channel. These byproducts covered the strong acid sites and modified the channels to increase the selectivity of isobutene. Therefore, the deposition of carbon played a vital role in shape-selective catalysis. ${ }^{32}$ As the reaction time onstream continued, the conversion of $n$-butene, the selectivity of isobutene, and the yield of isobutene tended to be stable but slightly decreased over time. A yield of isobutene at 33-43 wt $\%$ was achieved, and the selectivity of isobutene was higher than $90 \%$ after the reaction was carried out for longer than 15 $\mathrm{h}$, indicating that the ZSM-35 catalyst had excellent stability. These results are comparable to the industrialized skeletal isomerization to isobutene with an isobutene yield of 28.35$47.5 \mathrm{wt} \%$ in the presence of various types of catalysts. ${ }^{5,33,34}$ In addition, for long-time running of 30 days, the catalyst synthesized under optimal conditions exhibited a slightly higher yield of isobutene than the commercial catalyst purchased from Langdale, as shown in Table S2.
Compared to the fresh catalysts, the regenerated catalysts showed slightly lower $n$-butene conversion in the initial $50 \mathrm{~h}$ but a similar conversion as the reaction progressed over time. Isobutene selectivity and yield of the regenerated catalysts were slightly lower than those of fresh catalysts, whereas the propene yield only varied slightly during the initial reaction. These catalytic performances suggested that the regenerated catalysts did not recover completely, but their performances were like those of the fresh catalysts, indicating that the regeneration process was effective. During the first $50 \mathrm{~h}$, the conversion and selectivity differed significantly because of the remaining carbon, altered pore structure, and new acidity level in the regenerated catalysts. This was verified by the following: temperature-programmed oxidation (TPO), $\mathrm{NH}_{3}-\mathrm{TPD}, \mathrm{N}_{2}$ adsorption-desorption, and Py-IR characterization.

TPO results (Figure $5 \mathrm{~d}$ ) showed that the fresh catalyst only exhibited a small deposition peak located at $210^{\circ} \mathrm{C}$ assigned to the surface-adsorbed $\mathrm{CO}_{2}$. The regenerated catalyst had only one weak peak centered at $670{ }^{\circ} \mathrm{C}$ because of a small amount of unburned carbon. Used catalysts- 6 and used catalyst- 200 obtained at respective reaction times of 6 and $200 \mathrm{~h}$ had two peaks centered at 460 and $670{ }^{\circ} \mathrm{C}$, indicating that there were two types of deposited carbons. Moreover, the carbon deposition increased substantially with the increase of the reaction time, indicating that the deactivation of the catalysts resulting from the carbon deposition was inevitable. ${ }^{34}$ It is known that the higher the degree of graphitization, the higher the ratio of $\mathrm{C} / \mathrm{H}$, and the more difficult it is to remove the material. ${ }^{35}$ Therefore, the peak at $460{ }^{\circ} \mathrm{C}$ resulted from the 

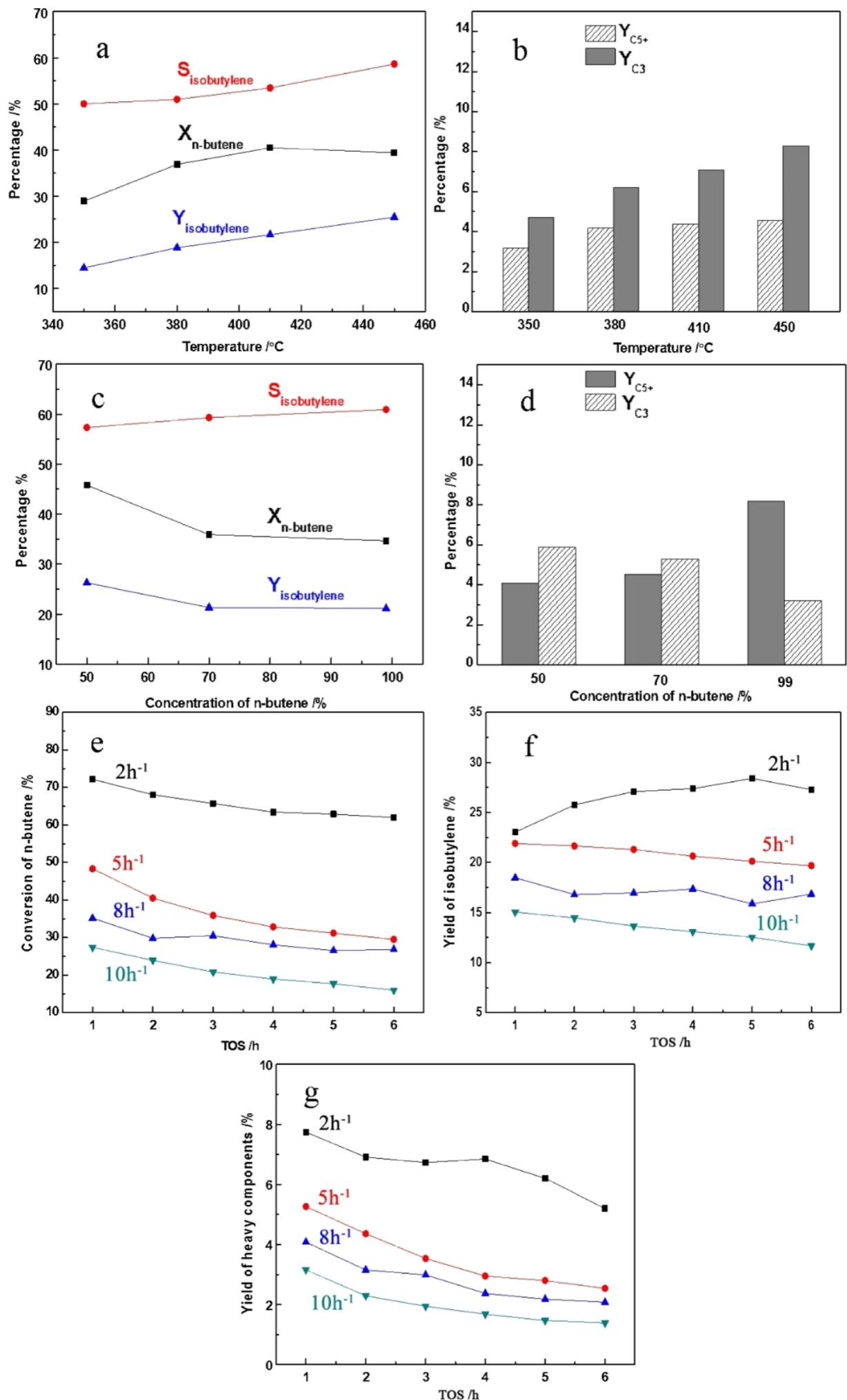

Figure 4. $(\mathrm{a}, \mathrm{b})$ Effect of reaction temperatures on the catalytic activity (reaction conditions: $n$-butene concentration $=50 \%$, pressure $=0.1 \mathrm{MPa}$, and WHSV $\left.=5 \mathrm{~h}^{-1}\right),(\mathrm{c}, \mathrm{d})$ effect of $n$-butene concentration on the catalytic activity (reaction conditions: $T=410{ }^{\circ} \mathrm{C}$, pressure $=0.1 \mathrm{MPa}$, and WHSV $=5 \mathrm{~h}^{-1}$ ), and $(\mathrm{e}-\mathrm{g})$ effect of WHSV on the catalytic activity (reaction conditions: $n$-butene concentration $=50 \%$, pressure $=0.1 \mathrm{MPa}$, and $T=410{ }^{\circ} \mathrm{C}$ ). The detailed component concentration in the feedstock is listed in Table S1.

adsorbed hydrocarbons and the carbon deposited on the catalyst surface area, whereas the peak at $670{ }^{\circ} \mathrm{C}$ was from the high polymer carbon (graphitelike structure). The similar peak areas at $670{ }^{\circ} \mathrm{C}$ for used catalyst- 6 and used catalyst-200 and the much larger peak area at $470{ }^{\circ} \mathrm{C}$ for used catalyst-200 suggested that the high polymer carbon (graphitelike structure) was formed at the initial stage of the reaction, whereas the lower polymer carbon was produced as the 

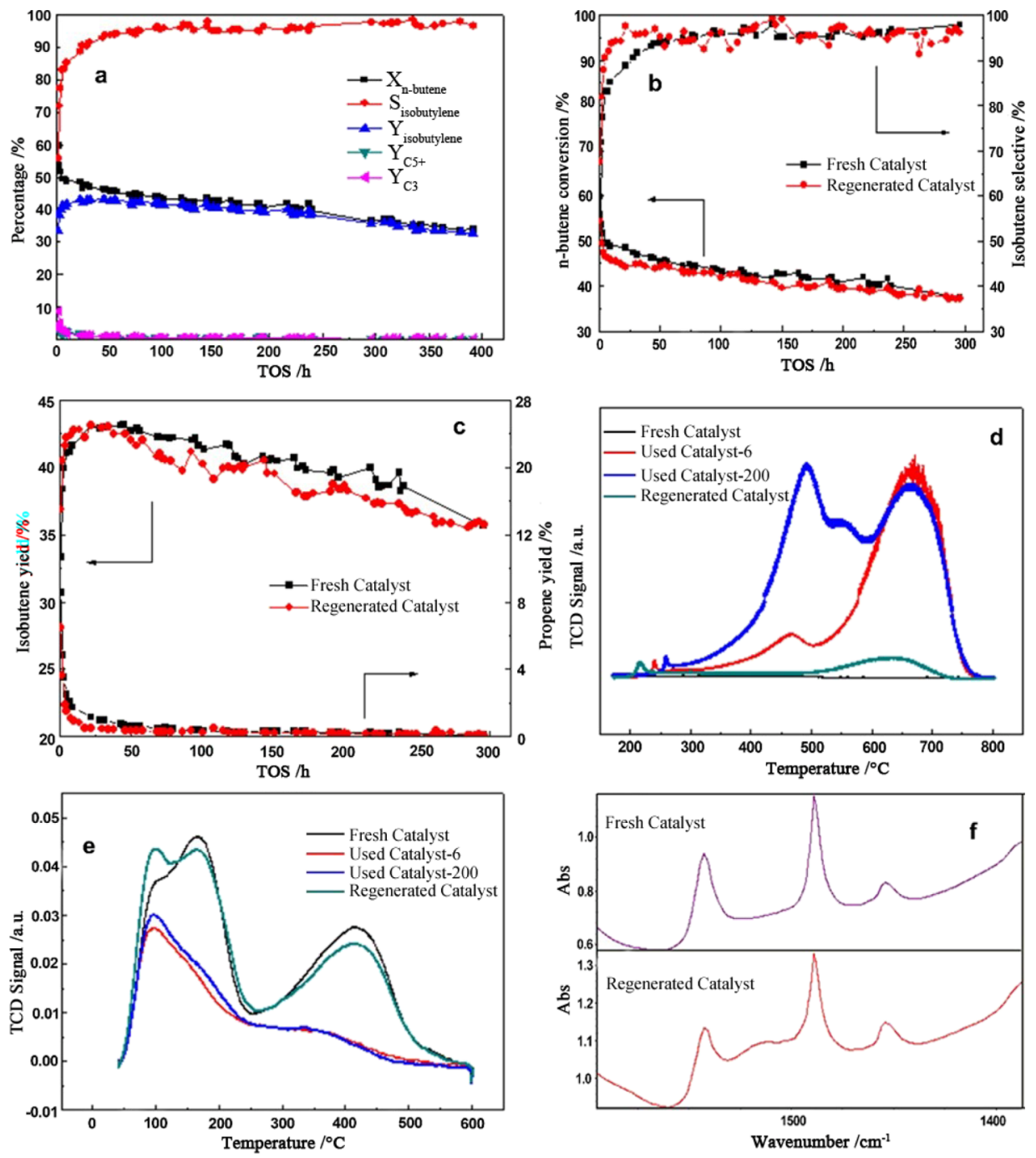

Figure 5. Stability and regeneration of ZSM-35 catalysts. (a) Stability test of ZSM-35 catalysts (feedstock: 50\% $i$-butene, optimized ZSM-35, $T=$ $410^{\circ} \mathrm{C}$, atmospheric pressure, WHSV $=5 \mathrm{~h}^{-1}$, and $\left.t=390 \mathrm{~h}\right),(\mathrm{b}, \mathrm{c})$ skeletal isomerization $n$-butene catalytic activity on fresh and regenerated ZSM-35 catalysts, (d,e) TPO and $\mathrm{NH}_{3}$-TPD profiles of fresh, used, and regenerated catalysts, and (f) Py-IR profiles of fresh and regenerated catalyst desorption at the temperature of $250{ }^{\circ} \mathrm{C}$.

reaction time increased. The remaining carbon or the interaction between the carbon and the zeolite may be one of the reasons for the improved selectivity.

$\mathrm{N}_{2}$ adsorption-desorption analysis results listed in Table 6 show that the surface area for used catalyst- 6 and used catalyst200 decreased dramatically and the pore size increased largely compared to the fresh catalyst. The longer the reaction time, the more obvious change of the surface area and the pore structure. The surface area decrease could be due to the blockage of the small size pores, indicating that the carbon

Table 6. $\mathrm{N}_{2}$ Adsorption-Desorption Analysis of Fresh, Used, and Regenerated Catalysts

\begin{tabular}{lcccc}
\multicolumn{1}{c}{ item } & $\begin{array}{c}\text { fresh } \\
\text { catalyst }\end{array}$ & $\begin{array}{c}\text { used } \\
\text { catalyst-6 }\end{array}$ & $\begin{array}{c}\text { used } \\
\text { catalyst-200 }\end{array}$ & $\begin{array}{c}\text { regenerated } \\
\text { catalyst }\end{array}$ \\
$\begin{array}{l}\text { surface } \\
\text { area } /\left(\mathrm{m}^{2} \cdot \mathrm{g}^{-1}\right)\end{array}$ & 323.4 & 59.75 & 35.8 & 260.1 \\
$\begin{array}{c}\text { pore } \\
\text { volume } /\left(\mathrm{cm}^{3} \cdot \mathrm{g}^{-1}\right)\end{array}$ & 0.1501 & 0.1699 & 0.1612 & 0.1595 \\
$\begin{array}{c}\text { average pore } \\
\text { size/nm }\end{array}$ & 0.55 & 1.9 & 3.03 & 0.64 \\
\end{tabular}

deposition occurred within the 8-rings, followed by the 10rings. Moreover, the deposited carbon may have formed macromolecular substances, which resulted in the increase of the pore size. ${ }^{36}$ The decreased surface area and the enlarged pore size in the regenerated catalyst further demonstrated that the catalysts have not been entirely rejuvenated, which further proved that the carbon deposition in the initial stage of the reaction cannot be combusted completely because of the higher polymerization degree and the larger graphitization degree. ${ }^{24}$ These results agreed with the TPO analysis results.

$\mathrm{NH}_{3}$-TPD analysis results (Figure 5e) indicated that there were two types of acid sites, including $100-200{ }^{\circ} \mathrm{C}$ for weak acid sites and $350-450{ }^{\circ} \mathrm{C}$ for strong acid sites. Compared to the fresh catalysts, both the weak and strong acid sites decreased dramatically for used catalyst- 6 and used catalyst200. There were almost no strong acid sites on the used catalysts. For different reaction times, the strong acid sites decreased to the same degree, but the weak acid sites decreased as the reaction time increased. This showed that the strong acid sites were covered by carbon before the weak acid sites. The active sites for the isomerization were primarily 
due to the weak acid sites because the selectivity of the isobutene increased with the time-on-stream. ${ }^{24}$ For the regenerated catalyst, the strong acid site amount decreased, inferring that there was remaining carbon, which covered the active sites in the regenerated catalysts. Because of the high amount of carbon deposition, it was impossible to characterize the used catalysts by Py-IR. Therefore, only fresh and regenerated catalysts were characterized by Py-IR (Figure 5f), where $1540 \mathrm{~cm}^{-1}$ was assigned to the B acid type and 1450 $\mathrm{cm}^{-1}$ was attributed to the L type. The Py-IR spectra indicated that the $\mathrm{B}$ acid type did not recover completely, whereas the $\mathrm{L}$ acid types were similar when compared to the fresh catalyst. Py-IR aligned well with the $\mathrm{NH}_{3}$-TPD results and showed that part of the deposited carbon remained strong in the $\mathrm{B}$ acid type, which corresponds well to the $\mathrm{N}_{2}$ adsorption-desorption and TPO results. This important discovery indicated that the carbon deposition could be adjusted by acid type and acid distribution. ${ }^{37,38}$

\section{CONCLUSIONS}

ZSM-35 catalysts were synthesized via a hydrothermal method and then formed for isomerization catalytic reaction. The amount of acidity strength and the type of formed ZSM-35 catalysts can be adjusted by adjusting the binder amount and hydrothermal treatment to maximize the production of isobutene. Taking the process capacity and economic performance of chemical companies into consideration, the optimized reaction conditions were $410{ }^{\circ} \mathrm{C}$ for the reaction temperature, $5 \mathrm{~h}^{-1}$ for the WHSV, and a $50 \%$ etherified $\mathrm{C} 4$ mixture concentration. In addition, the catalytic performance of the regenerated ZSM-35 catalysts after running $296 \mathrm{~h}$ was comparable to that of fresh catalysts, inferring that the regeneration process was excellent and effective. Coking enhanced the selectivity of isobutene because of the shapeselective reaction. This research is promising for the industrialization of the skeletal isomerization of $n$-butene to isobutene in the presence of formed and optimized ZSM-35 catalysts under optimal process conditions.

\section{EXPERIMENTAL SECTION}

Synthesis of ZSM-35 Zeolite Powder. ZSM-35 with a high pure phase and crystallization degree was synthesized via a hydrothermal method under the following experimental conditions: $\mathrm{SiO}_{2} / \mathrm{Al}_{2} \mathrm{O}_{3}=70$, alkalinity $=0.06$, crystallization temperature $=160{ }^{\circ} \mathrm{C}$, and crystallization time $=64 \mathrm{~h}$. Typically, $0.16 \mathrm{~g}$ of sodium metaaluminate and $0.25 \mathrm{~g}$ of sodium hydroxide were dissolved in water for $30 \mathrm{~min}$. Subsequently, $5.17 \mathrm{~g}$ of pyridine and $13.5 \mathrm{~g}$ of ludox (30.07, wt \%) were added and stirred for $30 \mathrm{~min}$ at room temperature. For current experimental conditions, the mole ratio of $\mathrm{Al}_{2} \mathrm{O}_{3}$, $\mathrm{SiO}_{2}, \mathrm{Na}_{2} \mathrm{O}, \mathrm{C}_{5} \mathrm{H}_{5} \mathrm{~N}$, and $\mathrm{H}_{2} \mathrm{O}$ is 1:69.1:4.2:x. After gelation was complete, the sol gel was transferred into an autoclave and crystallized at $160{ }^{\circ} \mathrm{C}$ for $64 \mathrm{~h}$. After the crystallization occurred, the autoclave was cooled to room temperature. The mixture was filtered with a frame filter and then washed at least 5 times with deionized water to ensure that the $\mathrm{pH}$ value of the washed water was less than 9. Subsequently, the filter cake underwent ion-exchange with $1 \mathrm{~L}$ aqueous solution of $1 \mathrm{M}$ ammonium nitrate twice at $90{ }^{\circ} \mathrm{C}$ for $5 \mathrm{~h}$ and was then washed with deionized water until free of chloride ions. The molecular sieve was dried at $200{ }^{\circ} \mathrm{C}$ for $3 \mathrm{~h}$ and then calcined at $350{ }^{\circ} \mathrm{C}$ at a heating rate of $1^{\circ} \mathrm{C} / \mathrm{min}$ for $4 \mathrm{~h}$ in a rotary kiln to obtain the ZSM-35 zeolite powder. The as-prepared zeolite was further formed, characterized, and tested for activity, which is explained in the following part.

Formation of ZSM-35 Catalysts. To satisfy the industrial requirement, ZSM-35 was formed into a clover shape to afford an improved mechanical strength to the catalyst. During the shaping process, the binder pseudo-boehmite amount and steam dealumination were systematically investigated to determine the optimal conditions. The anticrush strength of the formed catalysts was measured by a particle strength tester (model YHKC-3A). Details of the forming process are discussed in the Supporting Information, and the flow chart is shown in Figure S1.

Hydrothermal Treatment of the Catalyst. Approximately, $15 \mathrm{~g}$ of 3-5 mm catalysts was loaded into the reactor and hydrothermally treated at $550{ }^{\circ} \mathrm{C}$ and $0.3 \mathrm{MPa}$ for $1 \mathrm{~h}$ with a WGSH of $2 \mathrm{~h}^{-1}$. The details of the process are described in the Supporting Information, and the schematic of the hydrothermal treatment is shown in Figure S2.

Catalytic Reaction. Skeletal isomerization of $n$-butene was carried out in a fixed-bed continuous reaction apparatus (Figure S3) loaded with approximately $5 \mathrm{~g}$ of $2-3 \mathrm{~mm}$ diameter catalyst. The conversion of $n$-butene was monitored by varying the catalyst formed under various conditions, reaction temperature, concentration of $n$-butene, and WHSV. The temperature of the reaction was controlled by a temperature control cabinet (590U, Xiamen Yu Electric Automation Technology Co., Ltd), and the pressure was kept at atmosphere pressure. Different feedstock concentrations were obtained from an etherification factory. The product was analyzed using an Agilent GC-2000 II equipped with a flame ionization detector and an Agilent-GS-Alumina capillary column $(50 \mathrm{~m} \times 0.532 \mathrm{~mm})$. The $n$-butene conversion $(X$, wt $\%)$, isobutene selectivity $\left(S_{\mathrm{i}}, \%\right)$, isobutene yield $\left(Y_{\mathrm{i}}\right.$, wt $\left.\%\right)$, propylene yield $\left(Y_{\mathrm{p}}\right.$, wt $\left.\%\right)$, and heavy component of $\mathrm{C}_{5}^{+}$yield $\left(\mathrm{Y}_{\mathrm{C}_{5}}{ }^{+}\right.$, wt \%) were calculated according to eqs $1-5$, respectively.

$$
\begin{aligned}
& X=\frac{M w_{0 \mathrm{n}}-(M-P) w_{\mathrm{gn}}-P w_{\mathrm{ln}}}{M w_{0 \mathrm{n}}} \\
& S_{\mathrm{i}}=\frac{(M-P) w_{\mathrm{gi}}+P w_{\mathrm{li}}-M w_{0 \mathrm{i}}}{M w_{0 \mathrm{n}}-(M-P) w_{\mathrm{gn}}-P w_{\mathrm{ln}}} \\
& Y_{\mathrm{i}}=\frac{(M-P) w_{\mathrm{gi}}+P w_{\mathrm{li}}-M w_{0 \mathrm{i}}}{M w_{0 \mathrm{n}}} \\
& Y_{\mathrm{p}}=\frac{(M-P) w_{\mathrm{gp}}+P w_{\mathrm{lp}}-M w_{0 \mathrm{p}}}{M w_{0 \mathrm{n}}} \\
& Y_{\mathrm{C}_{5}}=\frac{(M-P) w_{\mathrm{gC}}+P w_{\mathrm{lC}}{ }^{+}-M w_{0 \mathrm{C}_{5}}{ }^{+}}{M w_{0 \mathrm{n}}}
\end{aligned}
$$

where $M$ is the mass flow rate $(\mathrm{kg} / \mathrm{h}), P$ is the recombination flow rate $(\mathrm{kg} / \mathrm{h})$, and $w$ is the mass fraction of the component (wt \%). Subscript 0 represents the raw material, g represents the gaseous product (gas phase of production after condensation), 1 represents the liquid product (liquid phase of production after condensation), $\mathrm{n}$ represents $n$-butene, i represents isobutene, $\mathrm{p}$ represents propylene, and $\mathrm{C}_{5}{ }^{+}$ represents the heavy component including five carbons or greater hydrocarbon in the liquid product. 
Regeneration of the Used Catalysts. The used catalysts were regenerated at a temperature of $330{ }^{\circ} \mathrm{C}$ first and then at $480{ }^{\circ} \mathrm{C}$ by burning the coke with $10 \%$ oxygen concentrations at a gas hourly space velocity of $2000 \mathrm{~h}^{-1}$ and a pressure of 0.1 $\mathrm{MPa}$. The effluent gas was analyzed via an Agilent GC2000 III analyzer. The regeneration process was completely finished when the $\mathrm{CO}_{2}$ concentration in the effluent gas was lower than $0.04 \%$.

Catalyst Characterization. The powder XRD patterns were carried out using a Bruker D8 ADVANCE X-ray diffractometer at $40 \mathrm{kV}$ with a $\mathrm{Cu} \mathrm{K} \alpha$ radiation source $(\lambda=$ $1.5406 \AA$ ) at $2 \theta$ ranging from 5 and $50^{\circ}$ with a step size of $0.02^{\circ}$. The diffraction lines were identified by matching them with reference patterns in the Joint Committee on Powder Diffraction Standards database.

$\mathrm{N}_{2}$ adsorption/desorption isotherms at $-196{ }^{\circ} \mathrm{C}$ were recorded using an ASAP2020M automatic surface ratio and aperture analyzer (U.S. Quantachrome). The samples were degassed in an $\mathrm{N}_{2}$ flow at $90^{\circ} \mathrm{C}$ for $1 \mathrm{~h}$ and were subsequently held at a temperature of $350{ }^{\circ} \mathrm{C}$ for $5 \mathrm{~h}$ before being measured. The specific surface area was calculated according to the Brunauer-Emmett-Teller (BET) method. The total pore volume was dependent on the adsorbed $\mathrm{N}_{2}$ volume at a relative pressure of approximately 0.99 . The micropore volume was obtained using the $t$-plotting method.

The morphology of these samples was investigated using a field emission scanning electron microscope (FEI, Quanta 200f) at an acceleration voltage of $40 \mathrm{kV}$ and a current of 40 $\mathrm{mA}$.

$\mathrm{NH}_{3}$-TPD was carried out on an AutoChem II 2920 analyzer manufactured by Micromeritics (USA) to determine the acidity strength of the catalyst. Approximately, $0.1 \mathrm{~g}$ of the sample was placed in a sample tube and then heated to $600{ }^{\circ} \mathrm{C}$ at $10{ }^{\circ} \mathrm{C} / \mathrm{min}$ under a $\mathrm{He}$ atmosphere for $1 \mathrm{~h}$ to remove the adsorbed molecular components. Subsequently, the temperature decreased to $40{ }^{\circ} \mathrm{C}$ under the $\mathrm{He}$ atmosphere, and then the sample was saturated with $10 \% \mathrm{NH}_{3} / \mathrm{He}$ for $1 \mathrm{~h}$. Weakly physisorbed unsaturated $\mathrm{NH}_{3}$ was removed with the He flow $(100 \mathrm{~mL} / \mathrm{min})$ for $30 \mathrm{~min}$. The chemisorbed $\mathrm{NH}_{3}$ was measured via a thermal conductivity detector with a temperature profile of $10^{\circ} \mathrm{C} / \mathrm{min}$ up to $600{ }^{\circ} \mathrm{C}$ and then held for 30 min under the same He flow.

Pyridine adsorption Fourier transform infrared (Py-IR) was used to determine $\mathrm{B}$ acid and $\mathrm{L}$ acid concentrations using a Nicolet-6700 infrared spectrometer (U.S., Nicolet). Approximately, $30 \mathrm{mg}$ of the sample powder was formed into selfsupporting tablets and then placed inside the reaction tank. The sample was purified at $450{ }^{\circ} \mathrm{C}$ for $2 \mathrm{~h}$ under high vacuum conditions of $1 \times 10^{-3} \mathrm{~Pa}$ and then saturated with the probe molecule pyridine at $90{ }^{\circ} \mathrm{C}$. After the program warmed up to the appropriate measurement temperature (fixed temperatures were 200 and $\left.350{ }^{\circ} \mathrm{C}\right)$, vacuum desorption $\left(1 \times 10^{-3} \mathrm{~Pa}\right)$ was carried out for $20 \mathrm{~min}$ and the sample was cooled to room temperature. The IR adsorption spectra of each temperature point were recorded. The adsorption peaks located at 1547 and $1445 \mathrm{~cm}^{-1}$ were characterized as B acid and L acid, respectively. The concentration of acid sites was calculated from the IR results using the extinction coefficient and integrated intensity of the desorption peak of pyridine and the sample weight reported by Emeis. ${ }^{25}$

According to the Lambert-Beer method, the amount of acid can be expressed as

$$
C=A /(K \cdot L)
$$

where $A$ is the absorbance, $K$ is the molar absorptivity, and $L$ is the thickness of the sample. Formula 6 can be simplified as

$$
\begin{aligned}
& C_{\mathrm{BPy}}=A_{\mathrm{BPy}} \cdot S_{\text {wafer }} /\left(K_{\mathrm{BPy}} \cdot m_{\text {wafer }}\right) \\
& C_{\mathrm{LPy}}=A_{\mathrm{LPy}} \cdot S_{\text {wafer }} /\left(K_{\mathrm{LPy}} \cdot m_{\text {wafer }}\right)
\end{aligned}
$$

where BPy represents the B acid position, LPy represents the $\mathrm{L}$ acid position, and $S$ is the surface area of the sample sheet. $K_{\mathrm{BPy}}$ is approximately $0.059, K_{\mathrm{LPy}}$ is approximately 0.084 , and the acid unit is $\mu \mathrm{mol} / \mathrm{g}$. The diameter of the sample piece $R=1.3$ $\mathrm{cm}$. Absorbance $A$ is obtained by integrating the peak areas in the plot 14450 and $1547 \mathrm{~cm}^{-1}$.

$\mathrm{O}_{2}$-TPO was performed on an AutoChem 2920 automated equipment (U.S., Micromeritics) and monitored using a QIC20 mass spectrometer (British Hyde). A sample ( $0.1 \mathrm{~g}$ ) was purged for 10 min under a $\mathrm{He}$ atmosphere, and then the temperature was increased to $800{ }^{\circ} \mathrm{C}$ at a heating rate of 10 ${ }^{\circ} \mathrm{C} / \mathrm{min}$ with $10 \% \mathrm{O}_{2} / \mathrm{He}(50 \mathrm{~mL} / \mathrm{min})$. The signals of $\mathrm{m} / \mathrm{z}=$ $4,18,32$, and 44 were detected by mass spectrometry.

${ }^{29} \mathrm{Si}$ magic-angle spinning NMR spectra were collected with a Bruker AVANCE III $500 \mathrm{MHz}$ spectrometer at 130.327 $\mathrm{MHz}$ with a $0.9 \mu$ s pulse width, $6 \mu$ s delay time, and $12 \mathrm{kHz}$ spinning speed.

\section{ASSOCIATED CONTENT}

\section{S Supporting Information}

The Supporting Information is available free of charge on the ACS Publications website at DOI: 10.1021/acsomega.8b00333.

Flow chart for forming ZSM-35 catalyst; schematic of the hydrothermal treatment of the catalysts; schematic of the continuous reactor for isomerization reaction; detailed information of the concentration of the feedstock; and comparison of the commercial and synthesized catalysts ZSM-35 (PDF)

\section{AUTHOR INFORMATION}

\section{Corresponding Authors}

*E-mail: xuquan@cup.edu.cn (Q.X.).

*E-mail: chzhw@126.com (Z.C.).

ORCID

Quan Xu: 0000-0003-2195-2513

Jason Street: 0000-0001-7317-216X

\section{Author Contributions}

The manuscript was written through contributions of all authors. All authors have given approval to the final version of the manuscript. Q.X. and Z.C. designed the experiments; W.Y. and Y.Y. carried out the experiments and characterizations; Y.L. and J.S. cowrote the paper; and Q.X., Z.C., H.Z. and C.X. analyzed the experimental data. All authors discussed the results.

Notes

The authors declare no competing financial interest.

\section{ACKNOWLEDGMENTS}

We thank Beijing Nova Program (no. Z171100001117058), Beijing Municipal Science and Technology Project (no. Z161100001316010), State Key Laboratory of Petroleum \& Petrochemical Pollution Controland Treatment (no. 
PPC2017015), Science Foundation of China University of Petroleum (Beijing) (no. 2462018BJC004), State Key Laboratory of Petroleum \& Petrochemical Pollution Controland Treatment (no. PPC2017015), and the National Institute of Food and Agriculture, U.S. Department of Agriculture, and McIntire Stennis under accession number 1009735 for the support.

\section{REFERENCES}

(1) Chu, W.; Li, X.; Zhu, X.; Xie, S.; Guo, C.; Liu, S.; Chen, F.; Xu, L. Size-controlled synthesis of hierarchical ferrierite zeolite and its catalytic application in 1-butene skeletal isomerization. Microporous Mesoporous Mater. 2017, 240, 189-196.

(2) Jo, D.; Hong, S. B. Mechanisms for the Reverse Skeletal Isomerization ofn-Butenes to Isobutene over Zeolite Catalysts. ChemCatChem 2017, 9, 114-116.

(3) Szostak, R. Handbook of Molecular Sieves: Structures; Springer Science \& Business Media, 1992.

(4) Onyestyák, G. Skeletal isomerization of butene over natural ferrierite. React. Kinet. Catal. Lett. 2007, 90, 179-186.

(5) Byggningsbacka, R.; Lindfors, L.-E.; Kumar, N. Catalytic Activity of ZSM-22 Zeolites in the Skeletal Isomerization Reaction of 1Butene. Ind. Eng. Chem. Res. 1997, 36, 2990-2995.

(6) Hu, H.; Ke, M.; Zhang, K.; Liu, Q.; Yu, P.; Liu, Y.; Li, C.; Liu, W. Designing ferrierite-based catalysts with improved properties for skeletal isomerization of n-butene to isobutene. RSC Adv. 2017, 7, 31535-31543.

(7) Sun, Z.; Hu, Y.; Xu, Y.; Xu, C. Study on activation of hierarchical pore ZSM-35 molecular sieve in butene skeleton isomerization reaction. Energy 2015, 4, 004.

(8) Guisnet, M.; Andy, P.; Gnep, N. S.; Benazzi, E.; Travers, C. Skeletal Isomerization ofn-Butenes. J. Catal. 1996, 158, 551-560.

(9) Xu, W.-Q.; Yin, Y.-G.; Suib, S. L.; Edwards, J. C.; OYoung, C.-L. n-Butene Skeletal Isomerization to Isobutylene on Shape Selective Catalysts: Ferrierite/ZSM-35. J. Phys. Chem. 1995, 99, 9443-9451.

(10) Cheng, Z.; Ponec, V. Fluorinated alumina as a catalyst for skeletal isomerization of n-butene. Appl. Catal., A 1994, 118, 127138.

(11) Houzvicka, J.; Ponec, V. Skeletal isomerisation of n-butene on phosphorus containing catalysts. Appl. Catal., A 1996, 145, 95-109.

(12) Liu, J.; Yu, L.; Zhao, Z.; Chen, Y.; Zhu, P.; Wang, C.; Luo, Y.; $\mathrm{Xu}$, C.; Duan, A.; Jiang, G. Potassium-modified molybdenumcontaining SBA-15 catalysts for highly efficient production of acetaldehyde and ethylene by the selective oxidation of ethane. J. Catal. 2012, 285, 134-144.

(13) Wiedemann, S. C. C.; Muñoz-Murillo, A.; Oord, R.; van Bergen-Brenkman, T.; Wels, B.; Bruijnincx, P. C. A.; Weckhuysen, B. $\mathrm{M}$. Skeletal isomerisation of oleic acid over ferrierite: Influence of acid site number, accessibility and strength on activity and selectivity. $J$. Catal. 2015, 329, 195-205.

(14) Corma, A.; Wojciechowski, B. W. The catalytic cracking of cumene. Catal. Rev. 1982, 24, 1-65.

(15) Houzvicka, J.; Nienhuis, J. G.; Ponec, V. The role of the acid strength of the catalysts in the skeletal isomerisation of n-butene. Appl. Catal., A 1998, 174, 207-212.

(16) Corma, A.; Faraldos, M.; Martinez, A.; Mifsud, A. Hydrogen transfer on USY zeolites during gas oil cracking: Influence of the adsorption characteristics of the zeolite catalysts. J. Catal. 1990, 122, 230-239.

(17) Ferreira, M. L.; Rueda, E. H. Theoretical characterization of alumina and sulfated-alumina catalysts for n-butene isomerization. $J$. Mol. Catal. A: Chem. 2002, 178, 147-160.

(18) Jo, D.; Hong, S. B.; Camblor, M. A. Monomolecular Skeletal Isomerization of 1-Butene over Selective Zeolite Catalysts. ACS Catal. 2015, 5, 2270-2274.

(19) Andy, P.; Gnep, N. S.; Guisnet, M.; Benazzi, E.; Travers, C. Skeletal Isomerization ofn-Butenes. J. Catal. 1998, 173, 322-332.
(20) Finelli, Z. R.; Querini, C. A.; Fígoli, N. S.; Comelli, R. A. Skeletal isomerization of 1-butene on ferrierite: deactivation and regeneration conditions. Appl. Catal., A 1999, 187, 115-125.

(21) Guisnet, M.; Costa, L.; Ribeiro, F. R. Prevention of zeolite deactivation by coking. J. Mol. Catal. A: Chem. 2009, 305, 69-83.

(22) de Ménorval, B.; Ayrault, P.; Gnep, N. S.; Guisnet, M. n-Butene skeletal isomerization over HFER zeolites: Influence of $\mathrm{Si} / \mathrm{Al}$ ratio and of carbonaceous deposits. Appl. Catal., A 2006, 304, 1-13.

(23) Wattanakit, C.; Nokbin, S.; Boekfa, B.; Pantu, P.; Limtrakul, J. Skeletal isomerization of 1-butene over ferrierite zeolite: A quantum chemical analysis of structures and reaction mechanisms. J. Phys. Chem. C 2012, 116, 5654-5663.

(24) Bauer, F.; Chen, W.; Bilz, E.; Freyer, A.; Sauerland, V.; Liu, S. Surface modification of nano-sized HZSM-5 and HFER by pre-coking and silanization. J. Catal. 2007, 251, 258-270.

(25) Emeis, C. A. Determination of integrated molar extinction coefficients for infrared absorption bands of pyridine adsorbed on solid acid catalysts. J. Catal. 1993, 141, 347-354.

(26) Cañizares, P.; Carrero, A. Dealumination of ferrierite by ammonium hexafluorosilicate treatment: characterization and testing in the skeletal isomerization of n-butene. Appl. Catal., A 2003, 248, 227-237.

(27) Kiliç, E.; Yilmaz, S. Effect of different acidity modifications on the activity and selectivity on H-ZSM5 zeolites in n-butene isomerization. React. Kinet., Mech. Catal. 2014, 112, 283-294.

(28) Pellet, R. J.; Casey, D. G.; Huang, H. M.; Kessler, R. V.; Kuhlman, E. J.; Oyoung, C. L.; Sawicki, R. A.; Ugolini, J. R. Isomerization of $\mathrm{n}$-butene to isobutene by ferrierite and modified ferrierite catalysts. J. Catal. 1995, 157, 423-435.

(29) Kim, Y. T.; Chada, J. P.; Xu, Z.; Pagan-Torres, Y. J.; Rosenfeld, D. C.; Winniford, W. L.; Schmidt, E.; Huber, G. W. Low-temperature oligomerization of 1-butene with H-ferrierite. J. Catal. 2015, 323, 3344.

(30) Sripinun, S.; Suriye, K.; Ayudhyab, S. K. N.; Praserthdam, P.; Assabumrungrat, $\mathrm{S}$. Kinetic Study of 1-Butene Isomerization over Hydrotalcite Catalyst. World Academy of Science, Engineering and Technology International Journal of Environmental and Ecological Engineering. 2015; Vol. 9, (5), pp 599-602.

(31) Bastiani, R.; Lam, Y. L.; Henriques, C. A.; da Silva, V. T. Application of ferrierite zeolite in high-olefin catalytic cracking. Fuel 2013, 107, 680-687.

(32) Xu, W.-Q.; Yin, Y.-G.; Suib, S. L.; O’Young, C.-L. Coke formation and its effects on shape selective adsorptive and catalytic properties of ferrierite. J. Phys. Chem. 1995, 99, 758-765.

(33) Zhang, M.; Chen, Y.; Wang, L.; Zhang, Q.; Tsang, C.-W.; Liang, C. Shape Selectivity in Hydroisomerization of Hexadecane over Pt Supported on 10-Ring Zeolites: ZSM-22, ZSM-23, ZSM-35, and ZSM-48. Ind. Eng. Chem. Res. 2016, 55, 6069-6078.

(34) Gayubo, A. G.; LLorens, F. J.; Cepeda, E. A.; Bilbao, J. Deactivation and Regeneration of a Chlorinated Alumina Catalyst Used in the Skeletal Isomerization ofn-Butenes. Ind. Eng. Chem. Res. 1997, 36, 5189-5195.

(35) Guisnet, M.; Magnoux, P. Organic chemistry of coke formation. Appl. Catal., A 2001, 212, 83-96.

(36) Andy, P.; Martin, D.; Guisnet, M.; Bell, R. G.; Catlow, C. R. A. Molecular Modeling of Carbonaceous Compounds Formed Inside the Pores of FER Zeolite during Skeletal Isomerization ofn-Butene. J. Phys. Chem. B 2000, 104, 4827-4834.

(37) Pinar, A. B.; Márquez-Álvarez, C.; Grande-Casas, M.; PérezPariente, J. Template-controlled acidity and catalytic activity of ferrierite crystals. J. Catal. 2009, 263, 258-265.

(38) Jo, D.; Lee, K.; Park, G. T.; Hong, S. B. Acid site density effects in zeolite-catalyzed 1-butene skeletal isomerization. J. Catal. 2016, $335,58-61$. 